\title{
INTEGRALI PSICHONEUROLOGIJA IR GENETIKA
}

\author{
Danielius Serapinas ${ }^{1,2}$, Anna Serapiniené ${ }^{2}$, Rita Bandzevičienè ${ }^{1}$, Rūta Pukinskaité ${ }^{1}$, \\ Antanas Valantinas ${ }^{1}$ \\ ${ }^{1}$ Mykolo Romerio universiteto Psichologijos institutas, ${ }^{2}$ InMedica Alfa klinika
}

\begin{abstract}
Raktažodžiai: psichologija, psichofiziologija, epigenetika, psichoneuroendokrinologija.

Santrauka

Šiuolaikinejje psichologijoje bei psichoterapijoje daug žinoma bei kalbama apie minčių svarbą, streso profilaktiką ir pozityvaus mąstymo poveikị ligų profilaktikai ir gydymui. Nauji psichofiziologijos ir neuropsichoanalizès bei genetikos tyrimai padejo pamatą naujai mokslo krypčiai - psichogenetikai atsirasti. Psichogenetika bendraja prasme nagrinejja žmogaus psichinių ir genetinių mechanizmų tarpusavio sąveiką bei įtaką sveikatai. Atskirų genų, t.y DNR atkarpų, pasireiškimas arba nepasireiškimas yra ne mažiau svarbūs nei pati DNR struktūra. Šiuos genų funkcijos pokyčius, nesusijusius su branduolio DNR nukleotidu seku pokyčiais, nagrinejja genetikos mokslo šaka epigenetika. Epigenetinis (angl. epigenetic)efektas reguliuoja genų veikimą ir yra susijęs su paveldimais, tačiau potencialiai grižtamais, genų raiškos, bet ne pačios DNR sekos pokyčiais. Epigenetiniai veiksniai keičia genų pasireiškimą, drauge nekeisdami DNR struktūros bei pasižymi plastiškumu reaguojant ị išorinius ir vidinius veiksnius. Nauji mokslo tyrimai parodè, kad šiais veiksniais gali būti ne tik cheminès medžiagos ar maistas, bet ir psichologiniai: pozityvus mąstymas, optimizmas, adekvati reakcija ị stresą.
\end{abstract}

\section{Ivadas}

Kiekvienas iš mūsų tiek savo asmeniniame, tiek darbiniame gyvenime turime tam tikrą kompleksą teigiamų ir neigiamų minčių arba žodžių ir kažkuri svarstyklių pusé nusveria ị vieną arba kitą pusę. Dažnai to pasekmė yra ne tik mūsų savijauta, psichologinè būsena, bet taip pat ir fizinès bei dvasinès sveikatos išraiška. Netgi Pasaulinè sveikatos organizacija (PSO) teigia, kad žmogaus sveikata priklauso nuo to, kaip žmogus mąsto ir gyvena. Štai sąrašas, kuris parodo, nuo kokių veiksnių ir kiek priklauso sveikata:
- Gyvenimo būdas $50 \%$

- Paveldimumas $20 \%$

- Aplinka $20 \%$

- Medicina $10 \%$

(Pagal PSO)

Paveldimumas sveikatai yra labai svarbus. Žmogus gauna 46 chromosomas nuo pat pradejjimo momento, po lygiai pusę iš tèvo ir iš motinos. Tose chromosomose didžiąa dalimi jau yra užkoduota bazinè sveikata. Bazinè ta prasme, kad jeigu pritrūktų kažkokios chromosomos, jau pasireikštų liga nuo pat prenatalinio laikotarpio iki gimimo ir tuo labiau matytųi gimus. Jeigu genetinis rinkinys yra idealus ir nèra polinkio ị ligas, tai žmogus gali ir gyvendamas kenksmingomis sąlygomis išlaikyti stiprią sveikatą. Jeigu šeimoje yra paveldimų ligų, tai jau yra sudaromas genetinis medis, kurio pagalba galima išsiaiškinti, kokia yra tikimybe ligai pasikartoti.

Straipsnyje apžvelgsime pagrindines genetikos naujienas. Kaip minčių ir genų sąveika gali veikti atminties formavimąsi, senejjimą ir daugeli kitų procesų.

Darbo tikslas - įvertinti naujausiais žinias apie minčių, genų ir neuroprocesų sąveiką.

\section{Tyrimo objektas ir metodika}

Mokslinių straipsnių apžvalga su raktiniais žodžiais: gyvenimo būdas, atmintis, epigenetika, neurofiziologija.

\section{Rezultatai ir jų aptarimas}

Epigenetika - tai mokslas apie ląstelinius ir fiziologinius fenotipinių bruožų variantus, kurie yra sukelti išorinių arba aplinkos veiksnių, dèl kurių tam tikri genai išjungiami ar ijungiami ir taip daroma itaka genų nuskaitymui, o DNR sekoje pokyčiai nevyksta. Šiuo metu žinoma keletas cheminių procesų, kurie gali turèti epigenetini poveikị. Dažniausiai tarp jų sutinkami yra DNR ir baltymu modifikacijos: metilinimas, acetilinimas, fosforilinimas ir ubikvitino grupès perkèlimas. DNR metilinimas yra viena lengviausiai tiriamų modifikacijų. Metilo grupé paprastai prijungiama prie DNR fragmento, kuriame iš eilès pasikartoja citozino bazès (citidino nukleotidai) (1 pav.). 
Chromatino struktūros pakitimai reguliuoja DNR galimybę ,išsivynioti“ ir tikimybę, kad genas bus nuolatos aktyvus arba tylus. Kai DNR metilinta, tai nebegali vykti DNR transkripcija, o kartu nesigamina DNR koduojami baltymai . Tai reiškia, kad genas tuo atveju yra neekspresuojamas. Dalis genų yra aktyvūs, tai yra ekspresuojami, dalis - neekspresuojami. Bet kokių atsitiktinai pasirinktų žmonių DNR yra bent 99,7 proc. identiška, tačiau epigenetiniu lygiu žmonès yra labai skirtingi. Naujausi tyrimai šioje srityje netgi pasiūlè epigenetinę ligos atsiradimo hipotezę, pagal kurią net identiški dvyniai turètų skirtis epigenetiniu požiūriu, nors jų genomai yra identiški. Ištyrus 3-74 m. amžiaus 40 porų identiškų dvynių, buvo nustatyta, jog jaunesnès dvynių poros, kurios gyveno panašiomis sąlygomis ir daug laiko praleido kartu, pasižymėjo labai panašiais DNR metilinimo ir chromatino acetilinimo bruožais. Tuo tarpu vyresnių dvynių, ypač tų, kurie gyveno skirtingose aplinkose, DNR metilinimas ir histonu acetilinimas daugumoje tirtų audinių ląstelių (limfocituose, burnos epitelio ląstelèse, riebaliniame audinyje, tam tikruose raumenyse) buvo labai skirtingas. Ankstyvos vaisiaus raidos metu ịvairūs aplinkos veiksniai gali paveikti genų ekspresiją pakeisti vaisiaus epigenetinę raišką dar iki gimimo. Tirdama Bristolyje gyvenančias šeimas, mokslininko Pembrey grupé nustatè, kad tèvų, kurie pradèjo rūkyti anksčiau nei $11 \mathrm{~m}$. amžiaus, sūnūs buvo daug labiau nutukę nei jų bendraamžiai. Šis rūkymo sukeltas poveikis nepasireiške dukterims. Spèjama, jog dauguma epigenetinių pakitimų nèra perduodami palikuonims ir genai yra ,išvalomi“", kai spermatozoidas apvaisina kiaušialąstę. Tačiau kai kuriais atvejais mityba ir elgesys gali sukelti pakitimus, perduodamus per keletą kartų. Epigenetini poveiki gali turèti daugybė veiksnių: sunkieji metalai, pesticidai, degalų atliekos, tabako dūmai, hormonai, radiacija, virusai, bakterijos ir net iprasti maisto produktai.

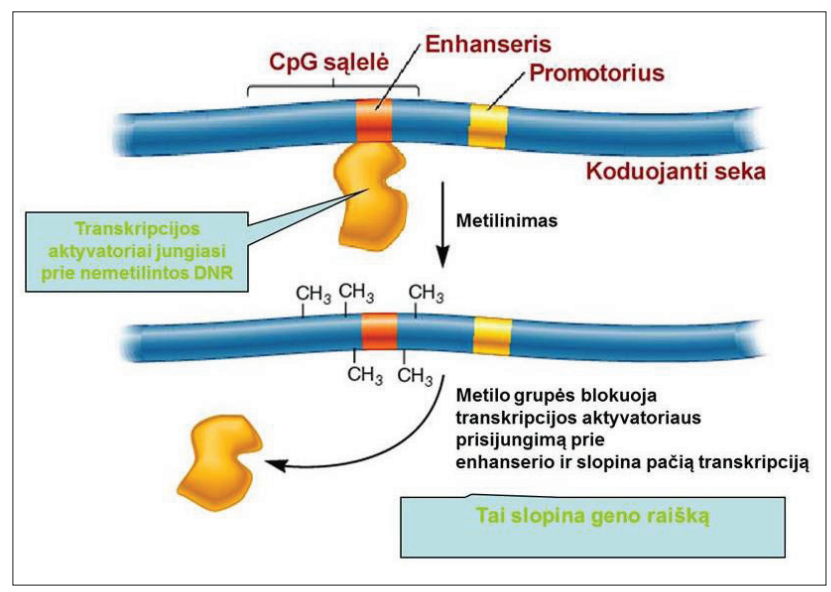

1 pav. Geno raiškos užslopinimas metilinant DNR
Morfogenai tai yra baltymai, arba sudètingi baltymų RNR kompleksai, kurie lemia ląstelès raidos galutinị rezultatą bei embriono raidos ypatumus. Besiformuojančioje moters kiaušialąsteje, priklausomai nuo moters sveikatos, psichologinès būklès, vartojamų vaistų bei bendrai gyvenimo būdo, yra gaminami morfogenai. Po apvaisinimo morfogenai pradeda veikti besiformuojantį embrioną, bei turi ịtakos jo raidai ir sveikatai.

Nauji mokslo tyrimai parode, kad epigenetiniais veiksniais gali būti ne tik cheminès medžiagos ar maistas, bet ir psichologiniai. Ne tik sveika něščiosios mityba, bet ir teigiamos mintys pozityviai veikia medžiagų apykaitą, o drauge generuoja hormonų bei transkripcijos faktorių gamybą, kurie, veikdami embriono genų ekspresiją, turi įtakos ne tik embriono raidai iki gimimo, bet ir po gimimo, netgi sveikatos būsenai paauglysteje ir suaugusiame amžiuje . Traumuojantys ịvykiai ir neigiamos mintys gali paveikti DNR metilinimo procesą ir sutrikdyti genų ekspresiją smegenų ląstelèse, kartu sukelti sveikatos sutrikimus žalingam veiksniui paveikus tiek iki gimimo, tiek po gimimo.

Netgi talentams atsirasti svarbi aplinkos ir genų sąveika. Jeigu vienas iš tévų turèjo tam tikrą talentą, pavyzdžiui, muzikinị, gali būti, kad vaikas taip pat pasuks tuo pačiu keliu. Taip nutinka dažniausiai dèl dviejų priežasčių. Viena jų - be abejo, genetinis paveldimumas. Kita vertus, gana didelę itaką daro ir aplinka. Pavyzdžiui, jeigu vaikas auga muzikalioje aplinkoje ir nuolat mato muzikuojančius tèvus, o ir šie stengiasi mažylị ugdyti, skiepyti jam tam tikrus gebejjimus ir talentus. Tad ir auklejjimo, ugdymo vaidmuo yra pakankamai svarbus, nepaisant genetinio komponento. Tai pagrindžia ir mokslininkų atlikti tyrimai, kurie nagrinèjo polinkị ị intelekto paveldimumą. Vykdant eksperimentą buvo atrinkta apie 40 iš vargingai gyvenusių Milvokio regiono (JAV) vaikų. 20 jų liko savo sąlygose kaip kontrolinè grupè, o 20 vaikų (tiriamoji grupè) buvo integruoti į aukšto visuomeninio lygio sąlygas (jų motinos gavo edukacinius mokymus, pagerintas gyvenimo sąlygas ir kt). Maždaug po 6 metų buvo patikrintas

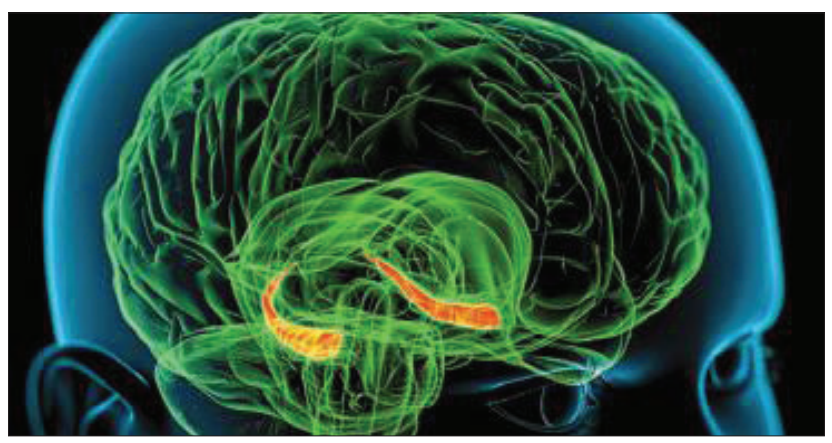

2 pav. Hipokampo lokalizacija smegenyse 
intelekto vidurkis tiek tų vaikų, kurie liko gyventi savo namų sąlygomis, tiek tų, kurių šeimos buvo integruotos ị pagerintas sąlygas. Paaiškejjo, kad pastarųjų mažylių intelekto koeficientas buvo daugiau kaip 20 vienetų didesnis nei vaikų, likusių gyventi įprastoje, tačiau vargingoje aplinkoje. Taigi intelektą, meninius gabumus galima ugdyti. Nors genai - itin svarbus veiksnys, tai nèra nuosprendis. Net apdovanotas žmogus gali viską iššvaistyti gyvendamas netinkamai, o saikingai talento gavęs asmuo sunkiai dirbdamas ir tobuledamas gali pasiekti labai daug.

Atminties psichogenetiniai mechanizmai. Pastarųu metų tyrimai parode, kad netgi atminties formavimesi yra svarbūs genetiniai mechanizmai, o ịsimenant tam tikrus ivykius genų aktyvacijos metu sintetinami baltymai, kurie pakeičia smegenų struktūrą. Nustatyta, kad trumpalaikių aplinkos stimulų sukeltiems molekuliniams pokyčiams išsaugoti reikalinga save ịamžinanti biocheminè reakcija smegenyse. Mokslininkai Crick ir Holliday, turèdami šią prielaidą, pasiūlè, kad epigenetiniai mechanizmai (būtent DNR metilinimas) turi šią biocheminę savybę, reikalingą ilgalaikei atminčiai susidaryti. Padarius šias išvadas pastaraji dešimtmetị buvo atlikta daug tyrimų, parodančių, kad epigenetiniai žymenys yra aktyviai ir laikinai reguliuojami neuronuose vykstant mokymosi ir atminties susidarymo procesams. Atsižvelgiant ị stabilią DNR metilinimo prigimtị vystymosi metu, buvo neịprasta atrasti dinamiškus ir DNR metilinimo pokyčius suaugusiujų CNS. Šis neịprastas epigenetinių mechanizmų veikimas privedè prie to, kad buvo suformuluota epigenetikos mokslo šaka, pavadinta neuroepigenetika (taip pat vadinama elgesio epigenetika). Kad epigenetiniai mechanizmai dalyvautų atskirų ir ịvairių atsiminimų formavimesi, modifikacijos turi reaguoti i aplinkos stimulų sukeltas signalų kaskadas. Gautos chromatino struktūros modifikacijos tuomet turi reguliuoti su atmintim susijusių genų raišką atitinkamuose nervų sistemos tinkluose. Kitaip tariant, epigenetinès modifikacijos turi būti aktyviai ir selektyviai indukuojamos specifinemis signalų kaskadomis specifiniuose genuose ir smegenų regionuose, kad būtų sukurti spefiniai atminties tipai. Laikinas genų ekspresijos specifiškumas ir baltymų sintezė skirtinguose smegenų regionuose - esminiai faktoriai ilgalaikès atminties formavimuisi ir išsilaikymui. Daugybė tyrimų parodé, kad mokantis yra indukuojama laikinos genų ekspresijos ir baltymų sintezès bangos hipokampe (2 pav.). Pirmi pokyčiai, atsirandantys po 3 val. mokymosi, yra svarbūs atminties formavimuisi, o vèlesni pokyčiai, atsirandantys tarp 12-24 val. po mokymosi, yra svarbūs atminties išlaikymui. Todèl galima suformuluoti praktinę rekomendaciją stengiantis kažką išmokti ar ịsiminti. Po intensyvaus mokymosi, tuo metu kai vyksta atminties genetinių mechanizmų įtvirtinimas, t.y. po 12-24 val, ypač svarbu vengti kenksmingų rizikos faktorių (alkoholio, psichotropinių vaistų, didelio streso ir kt.).

Genų ekspresijos pakitimai, dalyvaujantys išlaikant prisiminimus praejus daugiau laiko po mokymosi, yra indukuojami ankstesnių transkripcinių i̇vykių. Tyrimas parodė, kad blokuojant hipokampo BDNF (angl. Brain-derived neurotrophic factor) geno ekspresiją 12 val. po mokymosi, tai trukdè atsiminti po $7 \mathrm{~d}$.

Dauguma tyrimų apie epigenetinius mechanizmus atminčiai susidaryti parodè, kad epigenetiniai markeriai dinamiškai ir specifiškai reguliuojami per pirmuosius atminties formavimosi ir įtvirtinimo momentus. Atradimas, kad epigenetinès modifikacijos hipokampe yra laikinos, prieštaravo pradinei hipotezei, kad ilgalaikiai DNR metilinimo pakitimai lemia ilgalaikę atmintị. Viena teorija (The systems consolidation theory of memory maintenance) teigia, kad laikini epigenetinių markerių pakitimai hipokampe parodo laikiną hipokampo dalyvavimą formuojant atmintị. Pagal teoriją, atminties itvirtinimas vyksta hipokampe apie $7 \mathrm{~d}$., o senesni prisiminimai ( $>7 \mathrm{~d}$.) yra perduodami ị žievę. Tyrimai parodè, kad nauji prisiminimai siejami su pakitusia genų ekspresija hipokampe, bet senesni prisiminimai - su pakitusia genų ekspresija žievejje. Taigi smegenys yra visų praeities įvykių saugykla genų ir baltymų lygyje. Šie naujausi atradimai tik patvirtina molekuliniame lygyje seniai žinomas tiesas: „Ką pasėsi, tą ir pjausi“" ir „Kaip pašauksi, taip ir atsilieps“.

Psichosomatinė sveikatos apsaugos koncepcija. Žmogaus smegenys yra tiesiogiai susijusios su imunine sistema, antinkščiais ir periferiniais organais. Smegenys, imuninè sistema ir antinkščiai bei periferiniai organai (kepenys, kraujagyslès, inkstai ir kt.) yra vadinamoji ašis, ir jos viršuje yra smegenys. Tai reiškia, kad bet koks stresas, minčių kokybė gali veikti net ir konkrečių organų darbą. Nuo senų laikų jau ịrodytas mechanizmas, kaip stresas, kartu ir mintys veikia visą kūną. Tai yra anksčiau minèta ašis, vadinama: hipotalamo - hipofizès - antinkščiu ašis (liet. pagumburio - pasmegeninè - antinkščiu ašis). Šios ašies svarba, kad stresas atlieka ir pozityvią funkciją, irodyta jau senovejje. Jeigu atsiranda pavojus, žmogus susiduria su staigiu stresiniu faktoriumi, jis turi imtis tam tikrų priemonių, kad viskas būtu gerai. Tada jam padeda vadinamoji stresogeninè ašis (smegeninè antinkščių ašis), kurios aktyvacijos metu išsiskiria didelis streso hormono (kortizolio) kiekis antinkščiuose. Kortizolis paskatina išsiskirti kitus hormonus: adrenaliną, dopaminą, noradrenaliną. Adrenalinas yra streso hormonas, kuris turi savo konkrečią funkciją, jis padeda mobilizuoti jẻgas, kad žmogus galètų susikauti su ịvykusia grèsminga situacija. Adrenalinas pirmiausia padidina cukraus kiekị kraujyje, širdies susitraukimų dažnị. Kai stresas tampa lètinis ir trunka mènesius, tuomet ịvyksta antinkščių persti- 
muliavimas, t. y. išsiskiria labai didelis kiekis kortizolio ir adrenalino; atsiranda kraujagyslių, antro tipo diabeto, tam tikrų sąnarių ligų rizika bei silpsta imunitetas. Imunitetas silpsta, nes kortizolis slopina imuninę sistemą.

Streso prevencijos ir psichologinio nusiteikimo nauda sveikatai irrodo daugelis studijų. Vienoje studijoje aprašoma, kaip tikejjimas veikia subjektą, skiriant jam inertinę ar aktyviają medžiagą - pvz.: vienai grupei žmonių buvo duota paprasto pasaldinto vandens, bet pasakyta, kad tai yra emetikas (medžiaga, sukelianti vėmimą, pykinimą). Net $80 \%$ eksperimento dalyvių jis sukèlè pykinimą ar vèmimą. Kitai grupei žmonių taip pat buvo duota to paties pasaldinto vandens ir pasakyta, kad atsigaivintu. Šiai grupei jokio šalutinio poveikio nebuvo. Tai parodo, kaip svarbu geriant vaistus ar atliekant kitą kokị nors procesą, daryti su pozityviomis mintimis. Fiziologas Guy Sapirstein išanalizavo 39 studijas apie depresiją nuo 1974 iki 1995 metų. Jis padare išvadą, jog tikrasis farmakologinis efektas dèl vaisto poveikio sudarè $27 \%$ gydymo efektyvumo, $50 \%$ sudare placebo efektas ir $23 \%$ dèl nespecifiniu arba konteksto faktorių poveikio. Tai rodo, kad požiūris ir paciento įsitikinimas, jog jam padès, yra labai svarbus. Atsakymas ị visa tai yra mūsų smegenys, nes ten, ypač gumbure (lot. Thalamus) ir pagumburyje (lot. Hypothalamus) yra labai unikali laboratorija. Tai yra endokrininis organas liaukos, kurios gamina hormonus, dèl to ši dalis vadinama neuroendokrinine. Iš smegenų žievès tiesiogiai eina nerviniai laidai ị pagumburị ir gumburą. Tie laidai reiškia, kad mintys, ịvairūs požiūriai tiesiogiai kaip elektros signalai paveikia pagumburị ir sąlygoja atitinkamų medžiagų gamybą, ir priklausomai nuo minčių turinio gaminasi atitinkamos medžiagos, kurios veikia visą organizmo pusiausvyrą.

Ilgametis Amerikos psichologų asociacijos prezidentas M. Seligmanas, parodydamas mąstymo kokybès įtaką sveikatai, netgi ịvedè pozityvios sveikatos terminą. Pozityvi sveikata apibūdina būseną, platesnę nei ligų nebuvimas, tiek biologine, tiek subjektyviaja, tiek funkcinių matavimų prasme. Tam prielaidas sudare tai, kad šiuolaikine psichiatrija ir psichologija daug nuveikè dèl psichinių ligų, kančios, depresijos, nerimo, pykčio, prievartos pasekmių mažinimo. Tačiau mažai nuveikè psichinès sveikatos išsaugojimo sferose: teigiamos emocijos, pasišventimas, prasmigumas, pasiekimai, geri santykiai. Žemiau pateikiami tyrimai, kurie parode, kad teigiamos emocijos paskatina kūrybinị mąstymą. Pozityviai nusiteikę gydytojai netgi tiksliau nustatydavo kepenų ligos diagnozę. Optimizmas gerina gyvenimo kokybę bei prognozę po vainikinių kraujagyslių operacijos, širdies transplantacijos, saugo nuo insulto, greito ŽIV progresavimo bei bendro mirtingumo lygio vyresniame amžiuje. Pozityvus emocinis stilius (PES) apsaugo nuo "peršalimo" ligų. Aukštesnis PES lygis sveikiems savanoriams, kuriems ị nosị buvo sulašinti lašai su rinovirusu ar gripo virusu, buvo susijęs su mažesne viršutinių kvẻpavimo takų infekcijos rizika.

Ilgaamžiškumo genetika. Žmogaus senejjimą ir ilgaamžiškumą apsprendžia genų ir aplinkos veiksnių sąveika. Iš genetinių veiksnių svarbūs apoptozès, autofagijos, DNR reparacijos genai bei telomerai. Kiekvienos chromosomos gale yra telomerai, kurie apsaugo chromosomą bei DNR grandinę nuo suirimo ir yra tiesiogiai susiję su senèjimu. Kiekvieną kartą pasidalijus ląstelèms, telomerų ilgis palaipsniui trumpèja, kol galiausiai pasiekia kritiškai trumpą ilgị. Dèl šios priežasties DNR tampa pažeidžiama, o ląstelès nustoja dalytis bei pradeda senti, kartu sendinamas visas kūnas. Mokslo tyrimai įrodè, kad žmogaus ląstelèse yra fermentas telomerazé, kuris gali pailginti ir iš dalies atstatyti telomeru ilgị. O ši fermentą veikia ir išoriniai veiksniai: vaistai, mityba, rūkymas, virusai, aplinkos užterštumas ir kiti faktoriai. Kone stipriausią teigiamą poveikị daro fizinis aktyvumas, mankšta, ypač vadinamieji „Penki Tibeto pratimai“". Ydomūs profesorès Elizabet Blackburn, gavusios Nobelio premiją už ilgaamžiškumo genetikos išaiškinimą, tyrimai. Ji nustatè, kad psichologiniai veiksniai gali pagreitinti ir sulètinti telomerų trumpejjimo procesą (chroniškas stresas, pyktis pagreitina, o gera nuotaika, geranoriškumas, meilè lètina telomerų trumpėjimą). Ne veltui senovès išmintis byloja, kad pyktis, tai yra kerštas sau už kitų kaltes. Gauti duomenys rodo atsakomybės už minčių turinị svarbą, nes mintys gali pagerinti ịvykius arba pabloginti ịvykius, situaciją. Taigi, mūsų gyvenimo patyrimas: mąstymo būdas, emocijos ir elgesys veikia netgi genus, o šie procesai yra potencialiai grị̌tami.

\section{Išvados}

1. Sveikatos apsaugos darbuotojai ir psichologai turètų pacientams parodyti minčių itakos sveikatai svarbą šiuolaikinių psichofiziologinių tyrimų kontekte.

2. Integralios neuroendokrinologijos kurso itraukimas ì medicinos studijų ir rezidentūros programą prisidètų prie gilesnio ligų patogenezès supratimo ir jų gydymo bei prevencijos igyvendinimo.

3. Šiuolaikiniai telomerų ryrimai bei psichofiziologinių pratimų (,mindfulness“, malda, joga, meditacija) reikšmè telomerazès aktyvumui tampa prioritetine psichogenetikos kryptimi.

\section{Literatūra}

1. Kim S and Kaang BK. Epigenetic regulation and chromatin remodeling in learning and memory. Experimental \& Molecular Medicine 2017; 49, e281.

https://doi.org/10.1038/emm.2016.140 
2. Zovkic IB, Guzman-Karlsson MC, Sweatt JD. Epigenetic regulation of memory formation and maintenance. Learn Mem 2013;20(2):61-74.

https://doi.org/10.1101/1m.026575.112

3. Isen AM. 2005A Role for neuropsychology in understanding the facilitating influence of positive affect on social behavior and cognitive processes. Handbook of positive psychology. Oxford university press.

4. Miller I, Mill RA, Webb B. Quantum Bioholography. DNA Decipher Journal 2011; 1(2): 218-244.

5. Montagnier L, Aïssa J, Ferris S. et al. Electromagnetic signals are produced by aqueous nanostructures derived from bacterial DNA sequences. Interdisciplinary Sciences 2009; 1(2): 81-90. https://doi.org/10.1007/s12539-009-0036-7

6. Seligman MEP. Positive health. Applied Psychology 2008; 57 (1): 3-18. https://doi.org/10.1111/j.1464-0597.2008.00351.x

7. Weaver IC, Cervoni N, Champagne FA. et al. Epigenetic programming by maternal behavior. Nature Neuroscience. 2004; 7: 847-854.

https://doi.org/10.1038/nn1276

8. Epel E, Daubenmier J, Moskowitz JT. et al. Can meditation slow rate of cellular aging? Cognitive stress, mindfulness, and telomeres. Annals of the New York Academy of Sciences 2009; 1172: 34-53. https://doi.org/10.1111/j.1749-6632.2009.04414.x

9. Hunter P. The psycho gene. EMBO Rep 2010; 11(9): 667-669. https://doi.org/10.1038/embor.2010.122

10. Kangaspeska S, Stride B, Metivier R. et al. Transient cyclical methylation of promoter DNA. Nature 2008; 452: 112-115. https://doi.org/10.1038/nature06640

11. Barreto G, Schafer A, Marhold J. et al. Gadd45a promotes epigenetic gene activation by repair-mediated DNA demethylation. Nature 2007; 445: 671-675.

https://doi.org/10.1038/nature05515

12. Ma DK, Jang MH, Guo JU. et al. Neuronal activity-induced gadd45b promotes epigenetic DNA demethylation and adult neurogenesis. Science 2009; 323:1074-1077.

https://doi.org/10.1126/science.1166859

13. Wolkowitz OM. Of sound mind and body: depression, disease, and accelerated aging. Dialogues in Clinical Neuroscience $2011 ; 13 ; 25-39$.

14. Krishnan V, Nestler EJ. Linking molecules to mood: new insight into the biology of depression. The American Journal of Psychiatry 2010; 167: 1305-1320.

https://doi.org/10.1176/appi.ajp.2009.10030434
15. Miller I, Mill, R.A. \& Webb B. Quantum Bioholography. DNA Decipher Journal 2011; 1: 218-244.

16. Epel E, Daubenmier J, Moskowitz JT. et al. Can meditation slow rate of cellular aging? Cognitive stress, mindfulness, and telomeres. Annals of the New York Academy of Sciences. 2009; 1172: 34-53.

https://doi.org/10.1111/j.1749-6632.2009.04414.x

\section{INTEGRATIVE PSICHONEUROLOGY AND GENETICS \\ D. Serapinas, A Serapinienė, R. Bandzevičienè, R. Pukinskaitè, A. Valantinas}

Key words: psychology, psychophysiology, epigenetics, psycho-neuroendocrinology.

Summary

There are many knowledge and notes in the contemporary psychology and psychotherapy about the importance of thoughts, prevention of stress and positive thinking for the disease prophylaxis and treatment. New research in psychophysiology, neuropsychoanalysis and genetics laid a foundation for the development of new science direction, i.e. psycho-genetics. In general sense, psycho-genetics investigates the interaction between mental and genetic mechanisms, and their health effects. The manifestation or non-expression of separate genes, or DNA fragments, is no of less importance than the actual structure of DNA. The changes of genes' function which are not related with changes of nuclear DNA nucleotides sequencing are under the focus of a branch of genetic science, i.e. epigenetics. The epigenetic effect regulates a performance of genes and is related with inherited, therefore potentially reversible, changes of genes' manifestation but not a structure of DNA. Epigenetic factors transform an expression of genes without changing a structure of DNA, and has plasticity in response to external and internal factors. New research has shown that these factors may be not only chemicals or food, but also psychological in nature such as following: positive thinking, optimism, adequate reaction to stress.

Correspondence to: dserapinas@gmail.com

Gauta 2017-06-12 